\title{
Virtuális valóság alapú taktikai szimulációs kiképzőeszközök hazai fejlesztési lehetőségei I. rész: Technológiai áttekintés
}

\section{Domestic Development Opportunities of Tactical Simulation Training Devices based on Virtual Reality, Part I: Technological Overview}

Az informatika és mikroelektronika technológiai fejlődésével a virtuálisvalóságeszközök egyre hatékonyabbá válnak, egyre nagyobb beleélést, a valóság egyre pontosabb szimulációját teszik lehetővé. Ezt a technológiát a gazdaságilag fejlettebb államok katonai és rendvédelmi szervezetei már több mint egy évtizede kezdték el alkalmazni különböző területeken. Jelen tanulmányban azt kívánom igazolni, hogy ez a technológia mára elérte azt a fejlettségi szintet és modularitást, amikor alkalmazott kutatások eredményeként olyan saját eszközöket tudunk fejleszteni, amelyek akár nemzetközi szinten is piacképes alternatívát jelenthetnek a magas költségü rendszerekkel szemben, és amelyekkel a kiképzés bizonyos területei forradalmasíthatók. A cikksorozat első részében azoknak a könnyen hozzáférhető termékeknek és technológiáknak jellemzőit vizsgálom, amelyek az ilyen irányú törekvéseket hatékonyan képesek támogatni.

Kulcsszavak: virtuális valóság, harcászati szimuláció, szimuláció, gyakoroltató eszköz, kiképzés

Through the recent immense development in information technology and microelectronics, virtual reality (VR) devices have become increasingly sophisticated, providing close-to-real life experiences. VR technology has proved to be an essential training tool in various military and law enforcement applications for over a decade. My article series is aimed at uncovering the remarkable in-house development possibilities 
based on the modular nature of this technology. Through applied research, these state-of-the-art VR platforms may deserve international recognition and also have the potential to revolutionise certain components of military training. In the first part of my series, my objective is to give an overview of easily accessible products and technologies that enable us to turn the above mentioned goals into reality, whereas the second part is intended to compare the key parameters and capabilities of these solutions and modules with the characteristics of different training areas. In addition, my articles also discuss certain further prerequisites of successful in-house national developments.

Keywords: Virtual Reality (VR), tactical simulation, military training, law enforcement training

\section{Bevezetés}

A katonai és rendvédelmi szervek személyi állományának kiképzése, komplex feladatokra, valós szituációkra történő életszerü felkészítése és a kapcsolódó eljárásrendek begyakoroltatása eszköz-, anyag- és időigényes folyamatokat jelent. A rendszeresített haditechnikai eszközök használatára történő felkészítést támogató különböző szimulációs, gyakoroltató rendszereket külföldről, drágán szerzik be, míg az éles vagy szimulált lőgyakorlatok esetén a különleges, magasabb szintű készségeket fejlesztő kiképzési formák nem érhetők el a teljes állomány számára, illetve azok nehezen illeszthetők be a jelenlegi kiképzési gyakorlatba. A katonai és rendvédelmi szervek alegységeinek harci, beavatkozási, túlélési képességei egyértelműen függenek az egyes emberek képzettségének színvonalától. A kiképzés és felkészítés modern technológiákkal való támogatása - beleértve a virtuális valóság (Virtual Reality - VR) szimulációs eszközöket - és az ehhez igazított képzési tervek bevezetése költséghatékony megoldást jelenthet, és mérhető képességnövekedéssel járhat a Magyar Honvédség, valamint a rendvédelmi szervek számára egyaránt. A terület modernizációs törekvéseivel kapcsolatban figyelembe kell vennünk, hogy a civil szféra fejlesztési és termelési képességének gyorsulását a hazai haditechnikai kutatás-fejlesztés csak részlegesen, illetve csak késve követi le, ami nemcsak gazdasági okokból, hanem a polgári célú fejlesztések technológiai és módszertani fókuszának eltolódásából is adódik. A különböző szimulációk, ideértve a virtuálisvalóság-szimulációkat is, elterjedőben vannak a katonai kiképzés területén, és már hazánkban is található ilyen eszközt alkalmazó szimulátorközpont, például Szolnokon. ${ }^{2}$ Az ilyen szimulátoroknak elsősorban a repülésben van nagy hagyománya, ott a szimuláció mint képzési, kiképzési eszköz már 1910 körül megjelent, amikor az első fahordókból összeállított mechanikus repülőgép-szimulátort megépítették és pilóták képzésére használták. ${ }^{3}$ Azóta a szimulációs gyakoroltató berendezések a pilótaképzés szerves részét képezik, olyannyira, hogy ezek

Trautmann Balázs: Képzelt repülés. 2019. Elérhető: https://regi.honvedelem.hu/cikk/115528_kepzelt_repules (A letöltés dátuma: 2020. 05. 20.)

3 P. Adorian - W. Staynes - M. Bolton: The Evolution of the Flight Simulator. London, Royal Aeronautical Society, 1979. 
a gyakorlati képzésben elfogadottak valós repült órák bizonyos mértékű kiváltására. ${ }^{4}$ A katonai, rendvédelmi szervek állományának harcászati, taktikai és lőkiképzésének VR-szimulációval való támogatottságának mértéke ugyanakkor ettől a szinttől még messze elmarad, holott jelentősége megkérdőjelezhetetlen. Alkalmazásuk megteremti a lehetőségét, hogy a személyi állomány egyéni készségeinek és kollektív képességeinek (költség)hatékony és biztonságos fejlesztésén keresztül növeljük az alegységek hadrafoghatóságát, harcértékét. Az alapkészségek közül talán a legfontosabb - beosztástól, az alkalmazott technológiáktól, a rendelkezésre álló eszközöktől vagy fizikai erőnléttől függetlenül - a lőkészség, a biztonságos fegyverhasználat, beszéljünk akár támadó célú, akár önvédelmi fegyverhasználatról, vagy az állampolgárok életének védelméről. Az Amerikai Tengerészgyalogság 29. parancsnokától (General Alfred M. Gray Jr.) hangzott el az a gondolat, hogy minden tengerészgyalogos mindenekelőtt és elsősorban lövészkatona. A szállóigévé vált mondás hangoztatását mára ugyan inkább már mellőzik, mivel a lövész fegyvernem érdemeit látszik kisebbíteni, ${ }^{5}$ ugyanakkor, az idézet lényegi elemét vizsgálva korábbi gondolatomat erősíti meg, miszerint a katonai és rendőri állomány esetében egyaránt a fegyverhasználatra való készségek megléte és szinten tartása a túlélés sikerének alapvető záloga. A VR-alapú kiképzőrendszerek a fenti készségek kialakítását (oktatását), a begyakorlást (kiképzést) és a szinten tartást egyaránt képesek hatékonyan (helyszín, idő, humán erőforrás, eszköz, lőszer, üzemeltetési, fenntartási költség) támogatni a hagyományos kiképzési formák eszköztárának kiegészítésével és arányának csökkentésével. Jelen írásban ugyanakkor nem célom bizonyítani a virtuális valósággal támogatott kiképzés hatékonyságát, mivel egyrészt ezek valós körülmények közti vizsgálatához még nem rendelkezünk elég gyakorlati tapasztalattal, az ilyen rendszerek felhasználása még csekély mértékü, terjedésük ugyanakkor folyamatos, ${ }^{6}$ másrészt külföldön több rendvédelmi és katonai szervezetben foglalkoztak már tudományos igényességgel a bennük rejlő lehetőségek elméleti vizsgálatával. ${ }^{7}$ Célom rámutatni arra, hogy ilyen rendszereket a kereskedelmi forgalomban is beszerezhető modulokból, hazai szoftver- és hardverfejlesztő, illetve rendszerintegrátori kapacitásokra alapozva képesek vagyunk saját célokra kifejleszteni. A hazai kutatás-fejlesztés elindításához holisztikusan kell vizsgálni azokat a tényezőket, amelyek a költséghatékonyságot és a további hosszú távú előnyöket biztosítják. A tényezők közül elsősorban magát a már rendelkezésre álló VR-technológiát, a kiképzési terület sajátosságait, valamint a fejlesztésekhez szükséges kompetencia-rendszert érdemes vizsgálni a nemzeti sajátosságok figyelembevételével. Azontúl azonban, hogy a fejlesztések sikeréhez a fenti három terület vizsgálata elengedhetetlen, annak érdekében, hogy az üzemben tartás és a teljes életciklus gazdaságossága is igazolható legyen, további szempontok elemzése is szükségessé válik.

4 53/2016. (XII. 16.) NFM rendelet a légijármű és a repülőeszköz személyzet, valamint a repülésüzemi tiszt képzéséről, vizsgáztatásáról, engedélyeiről és a képzésükben részt vevő képző szervezetek engedélyezéséről, 1. melléklet 1.2 .3 pont.

5 David Grove: Why the term "every Marine is a rifleman" needs to stop. 2018. Elérhető: www.wearethemighty. $\mathrm{com} /$ military-life/why-the-term-every-marine-is-a-rifleman-needs-to-stop (A letöltés dátuma: 2020. 05. 20.)

Rick Adams: Virtual Reality Ramp Up 3D Immersive Environments. Military Technology, 41. (2017), $12.42-44$.

7 Martin L. Blink et alii: Research Report 1986: Training Capability Data for Dismounted Soldier Training System. United States Army Research Institute for Behavioral and Social Sciences, 2015. Elérhető: https://apps.dtic.mil/ dtic/tr/fulltext/u2/a621959.pdf (A letöltés dátuma: 2020. 05. 20.) 


\section{VR-kiképzőeszközök a harcászati és taktikai képzésben}

A katonai és rendvédelmi szerveknél a fegyverhasználat környezete és szabályozása merőben különbözik. Ennek ellenére az intézkedéstaktika és a harcászat közös metszete, hogy komplex és bonyolult szituációkban kell gyors taktikai döntéseket hozni, a személyi fegyvereket szakszerüen és biztonságosan kell használni erős nyomás alatt is. A taktikai kiképzőrendszerek a lehető legmagasabb fokú komplexitást biztosítva, számos nehezítő tényezőt szimulálva interaktív szituációkba helyezik a felhasználókat, akik biztonságosan és költséghatékonyan gyakorolhatják a végrehajtandó feladatot, készségeket alakithatnak ki. A legtöbb ilyen rendszer ebből adódóan kettős felhasználású. ${ }^{8}$

Ha virtuálisvalóság-alapú kiképzőrendszerről, ezen belül is taktikai gyakoroltató eszközökről van szó, akkor immerzív VR-szimulációs rendszerekről beszélhetünk. Az immerzivitás lényege és jelentése, hogy a felhasználót úgy helyezzük át a - számítógép által generált és szimulációt futtató - virtuális térbe, hogy azt saját szemszögéből látja, testét és mozgását teljes beleéléssel valósnak érzékeli. Ahhoz, hogy ezt elérjék, ezeknek a VR-rendszereknek a legfontosabb eleme a virtuális audiovizuális ingerek átadásáért felelős, fejre rögzített, virtuálisvalóság-sisak, amelyet VR Headset-nek vagy Helmet-mounted Display-nek (HMD) is hívnak. A teljes immerzivitás elérése érdekében számos kiegészítő, mozgáskövető és egyéb beviteli technológia egészítheti ki a sisakokat. Ilyen rendszerek esetén referenciának tekinthető a védelmi ipar egyik nagy szereplője, a Raytheon által már 2010-ben kifejlesztett, szinte minden, a technológiában rejlő lehetőséget kiaknázó - meglehetősen költséges - „VIRTSIM" nevü rendszere, ${ }^{9}$ amely 2020-ban is használatban van a Maláj hadsereg Royal Ranger Regimentjénél. ${ }^{10}$

Ez a rendszer egészen 12 fős rajokig, erre a célra felkészített kosárlabdapálya méretü teremben tud gyakoroltatni különböző komplex rendvédelmi és katonai jellegű taktikai feladatokat. A rendszer lehetőséget ad több dimenzió mentén történő kiértékelésre is (after-action review), mint például a mozgások, taktikai döntések, procedúrák követésének utólagos elemzése. Az immerzivitást tovább növeli, hogy a taktikai, fegyverhasználati fogások, mint a tárcsere, fedezékhasználat, kommunikáció, kézjelek, érintések szintén modellezve vannak. 2010 óta számos cég és fegyveres szervezet foglalkozott a technológia kiképzési célú használatával, amelynek eredményeként egyre olcsóbban, egyre több funkcióval felvértezett, moduláris eszközökből felépülő rendszereket tudnak építeni. Az amerikai Animated Storyboards cég V-Armed divíziójának viszonylag friss rendszere sok saját fejlesztést tartalmaz, ${ }^{11}$ de itt már használnak készen kapott nyílt technológiát is, mint például az „Unreal Engine” 3D szimulációs szoftver komponenst (3D motor). ${ }^{12}$

8 Asterion VR cég weboldala: A ModulMaze környezeti csomagjai katonai és rendvédelmi feladatokat is tartalmaznak. Elérhető: https://asterionvr.com/ (A letöltés dátuma: 2020. 05. 20.)

9 Ben Lang: VIRTSIM is the Virtual Reality Platform That Gamers Crave but Can't Have. Road To VR. 2012. Elérhetö: www.roadtovr.com/virtsim-virtual-reality-platform/ (A letöltés dátuma: 2020. 05. 20.)

10 VIRTSIM by $9^{\text {th }}$ Ranger from $3^{\text {rd }}$ until $7^{\text {th }} F e b$. 2020. [Maláj Hadsereg - a szerző kiegészítése] Elérhető: www.youtube.com/watch?v=YOy8hT17-vE (A letöltés dátuma: 2020. 05. 20.)

11 Tammy Waitt: V-ARMED: Experience Next-Gen Simulation. 2019. Elérhető: https://americansecuritytoday. $\mathrm{com} / \mathrm{v}$-armed-experience-next-gen-simulation-learn-multi-vid (A letöltés dátuma: 2020. 05. 20.)

12 Unreal Engine, Training and Simulation. Elérhető: www.unrealengine.com/en-US/industry/training-simulation (A letöltés dátuma: 2020. 05. 20.) 


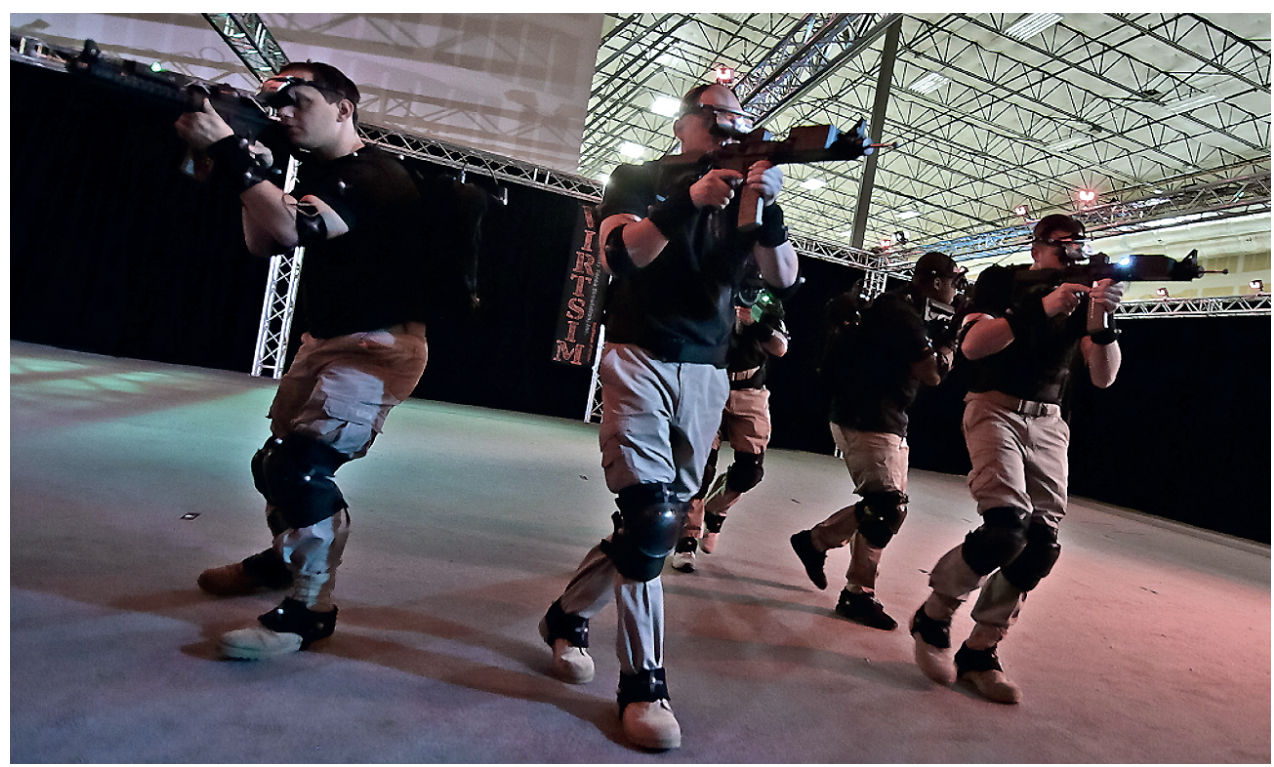

1. ábra

A 2010-ben elkészült Raytheon „VIRTSIM” nevü rendszere demonstráció közben.

Forrás: Lang i. m. (9. lj.)

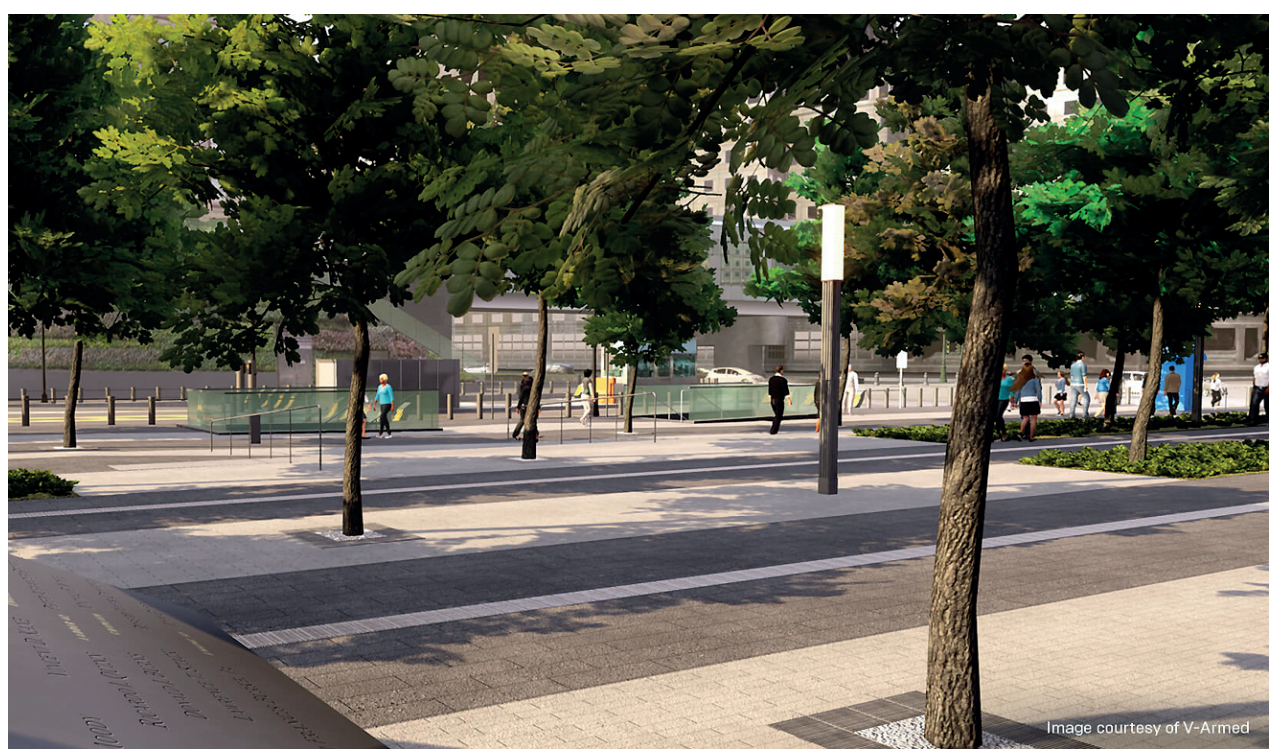

2. ábra

A V-Armed cég szimulátorának egyik szintetikus környezete a játékiparban elterjedt Unreal 3D-motort alkalmazva.

Forrás: Sébastien Lozé: Efficient police virtual training environment in VR by V-Armed. 2019. Elérhető: www. unrealengine.com/en-US/spotlights/efficient-police-virtual-training-environment-in-vr-by-v-armed (A letöltés dátuma: 2020. 05. 20.) 
A koreai Optimus System ${ }^{13}$ és az amerikai ONR Techsolutions ${ }^{14}$ rendszerei már látszólag szinte csak kereskedelmi forgalomban fellelhető modulokból építkeznek. (Ez utóbbi valójában egy „kevert valóság” rendszer, de felépítését tekintve estünkben is releváns). Az Optimus System eszközei esetén látható, hogy kereskedelmi forgalomban kapható alkatrészek segítségével végeznek kiegészítő követést a szimuláció valóságérzetének növelésére és a fegyverek digitalizálására. A VIRTSIM még a filmkészítésből átvett, helyhez kötött mozgáskövető (motion capture) megoldást használt, ${ }^{15}$ amelynek ára százezer dolláros nagyságrendü, és amely manapság hasonló minőségben megoldható már egy pár tízezer forintos Kinect szenzorral, valamint ingyenes szoftverkönyvtár alkalmazásával. ${ }^{16}$ A HMD-k esetén is nagy a változás, mivel az akkori rendszerhez képest manapság fél- vagy harmadösszegért, minimum kétszeres felbontású, kétszeres látószögü, többszörös kontrasztú és képfrissítési idejü eszközöket lehet beszerezni. ${ }^{17}$ A Motion Reality Inc. cég, amely a Raytheon partnere volt a VIRTSIM kifejlesztésében, a rendszert továbbfejlesztette, és továbbra is eladásra kínálja DAUNTLESS néven. ${ }^{18}$

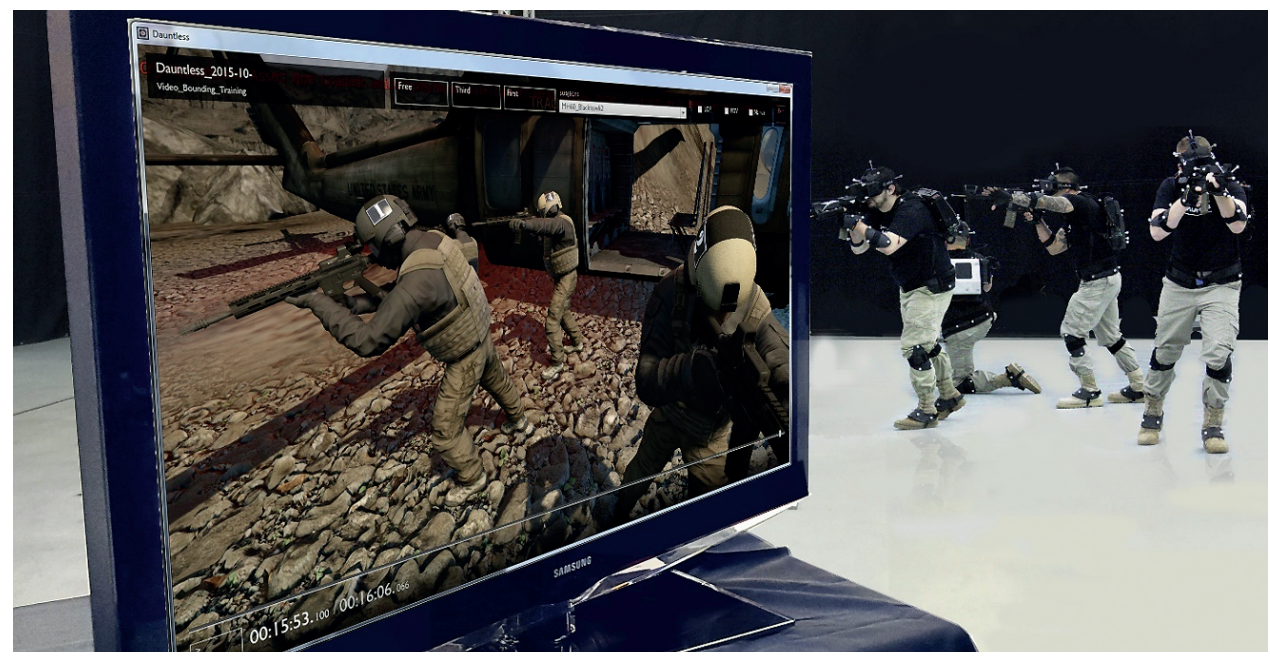

3. ábra

A szinte teljes immerzivitást adó Raytheon VIRTSIM-alapokra épülő DAUNTLESS taktikai VRkiképzőeszköz a Motion Reality cégtöl.

Forrás: Motion Reality, Inc. Twitter-bejegyzése. Elérhető: https://twitter.com/motionreality/ status/821380226919890944/photo/1 (A letöltés dátuma: 2020. 05. 20.)

13 Korean startup releases VR simulators for military training. Elérhető: www.youtube.com/watch?v=Et5BsVOU1Lw (A letöltés dátuma: 2020. 05. 20.)

14 Office of Naval Research (ONR) Global Techsolutions. Elérhetö: www.onr.navy.mil/techsolutions/ (A letöltés dátuma: 2020. 05. 20.)

15 A Motion Reality cég által fejlesztett megoldás a Polár Expressz és Avatar filmekben használt rendszerre épül.

16 Ayushi Gahlot et alii: Skeleton based Human Action Recognition using Kinect. International Journal of Computer Applications (0975 - 8887) Recent Trends in Future Prospective in Engineering \& Management Technology, (2016), 9-13. Elérhető: www.academia.edu/29068956/Skeleton_based_Human_Action_Recognition_using_Kinect (A letöltés dátuma: 2020. 06. 28.)

17 A használt eMagin Z800 HMD 800×600 felbontással és 40 fokos vízszintes látószöggel rendelkezett, 1600 dolláros áron.

18 DAUNTLESS. Elérhető: www.motionreality.com/dauntless (A letöltés dátuma: 2020. 05. 20.) 
Ez a rendszer ugyan már a kornak megfelelő, folyamatosan frissített hardver- és szoftverkörnyezettel rendelkezik, de az eredetivel azonos árkategóriában. A fenti példák jól mutatják a trendet, amiből látszik, hogy manapság a virtuálisvalóság-alapú rendszerek fejlesztésébe startupok is könnyedén vágnak bele a modulárisan, olcsón elérhető eszközökre építve. A technológia folyamatos fejlődése miatt a területre (piacra) történő belépés bármely időpontban aktuális és sikeres lehet. Ennek eredményeként akár nagy megbízhatóságú, jól müködő immerzív VR-technológiát lehet költséghatékonyan létrehozni, és saját fejlesztésű megoldásokkal folyamatosan utánkövetni, frissíteni, így - aktív szakértői (kiképzés, felkészítés) támogatás mellett - költséghatékonyan, technológiai kockázatok nélkül lehet tervezni és építeni az előbb említett DAUNTLESS-hez vagy az amerikai hadsereg által használt gyalogos katona kiképző rendszerhez $\left(\right.$ DSTS $^{19}$ ) hasonló platformokat. Ezt a lehetőséget megragadva, illetve szem előtt tartva, hogy a kiképzés modernizálása hozzájárul a rendvédelmi és honvédelmi szervezetek hatékonyságának növeléséhez, érdemes megvizsgálni saját, nemzeti sajátosságokat is figyelembe vevő rendszerek fejlesztésének lehetőségét. Az ilyen irányban történő gondolkodás egybevág a jelenlegi kormányzati törekvésekkel, miközben a nemzetbiztonsági, illetve nemzetgazdasági érdekeket egyaránt támogatja a kapcsolódó fejlesztési tevékenység hazai ipari innovációs bázison történő megvalósítása.

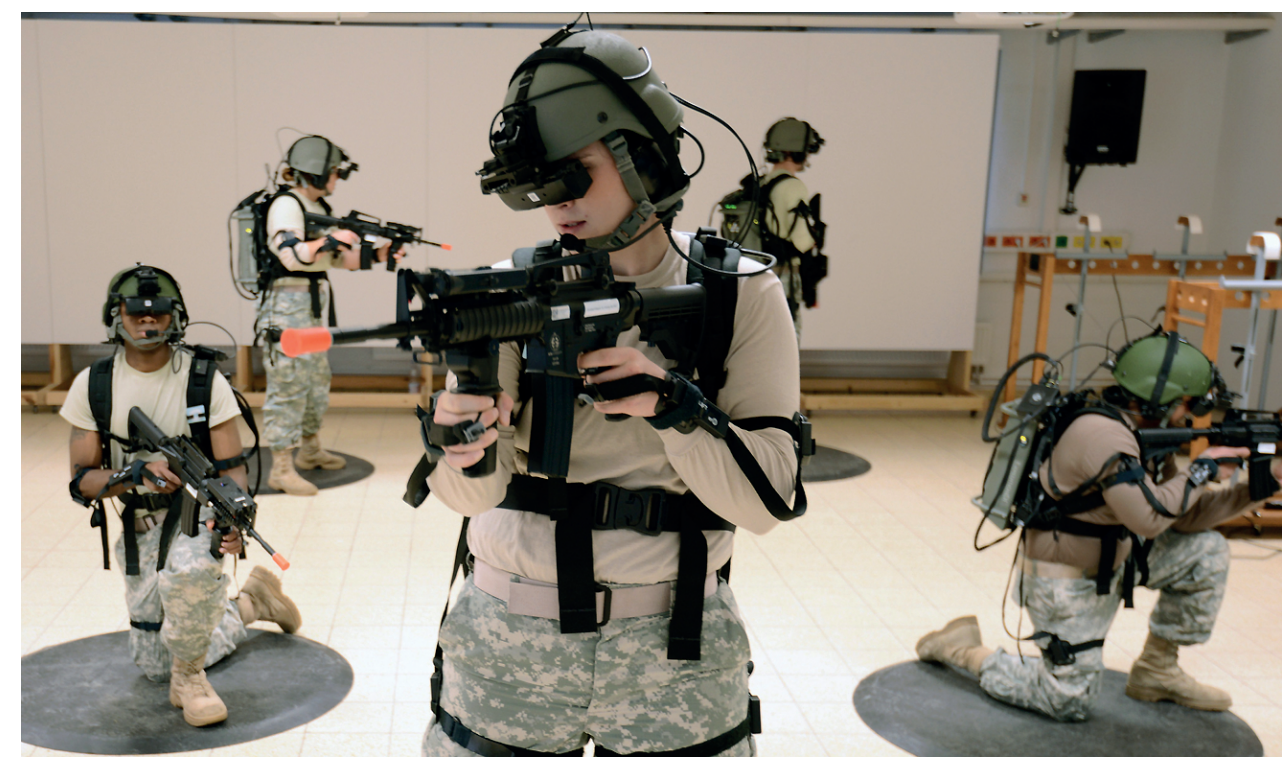

4. ábra

A széles körben alkalmazott amerikai "gyalogos katona kiképző rendszer” (DSTS) használata a U.S. Army 412 ${ }^{\text {th }}$ Aviation Support Battalion katonái által, Németországban, 2013-ban.

Forrás: Markus Rauchenberger: Dismounted Soldier Training (U.S. Army). Elérhető: www.flickr.com/photos/soldie rsmediacenter/11336074633/ (A letöltés dátuma: 2020. 05. 20.)

19 DSTS: Dismounted Soldier Training System - Gyalogos katona kiképző rendszer. 


\section{A fejlesztések VR-technológiai alapjai}

\section{A vizsgált eszközök}

A virtuálisvalóság-technológia, szemben a kiterjesztett (Augmented Reality - AR) és kevert valóság (Mixed Reality - MR) technológia eszközeivel, olyan fejen viselhetö, kijelzőkből, lencsékből, hangszórókból álló rendszert alkalmaz (HMD-, VR-sisak), amely igyekszik teljesen kizárni a valós környezet audiovizuális ingereit. Míg az ARés MR-rendszerek esetén a tényleges környezet képét látja a felhasználó, amelyre térben „rögzítve" és szinkronban vetítik rá a szintetikus térbeli képet, addig a VR-eszközök számítógép által generált háromdimenziós térbe helyezik a felhasználót, a kijelző képe a látótér nagy részét lefedi, a maradék látótérrészt pedig kitakarja. Az elemzésben nem a teljességre törekedve tekintem át a szóba jöhető VR-eszközök körét, hanem a technológia hozzáférhetőségét tartottam szem előtt. Ezért a Magyar Honvédség keretein belül, a szolnoki szimulátorközpontban már alkalmazott HTC Vive Pro (5. ábra) és a hasonló technikai lehetőségekkel rendelkező Oculus Rift ${ }^{20}$ rendszerek paramétereit vizsgálom. Ezek az eszközök a kereskedelmi forgalomban is könnyen beszerezhetők, így a fejlesztésekbe akár azonnal bevonhatók. Fontos megjegyezni, hogy a kereskedelmi forgalomban kapható termékek licenszelési, illetve kiberbiztonsági okokból nem minden esetben használhatók közvetlenül saját fejlesztések során, de prototipizáláshoz, valamint a technológiai képességek felméréséhez jól alkalmazhatók.

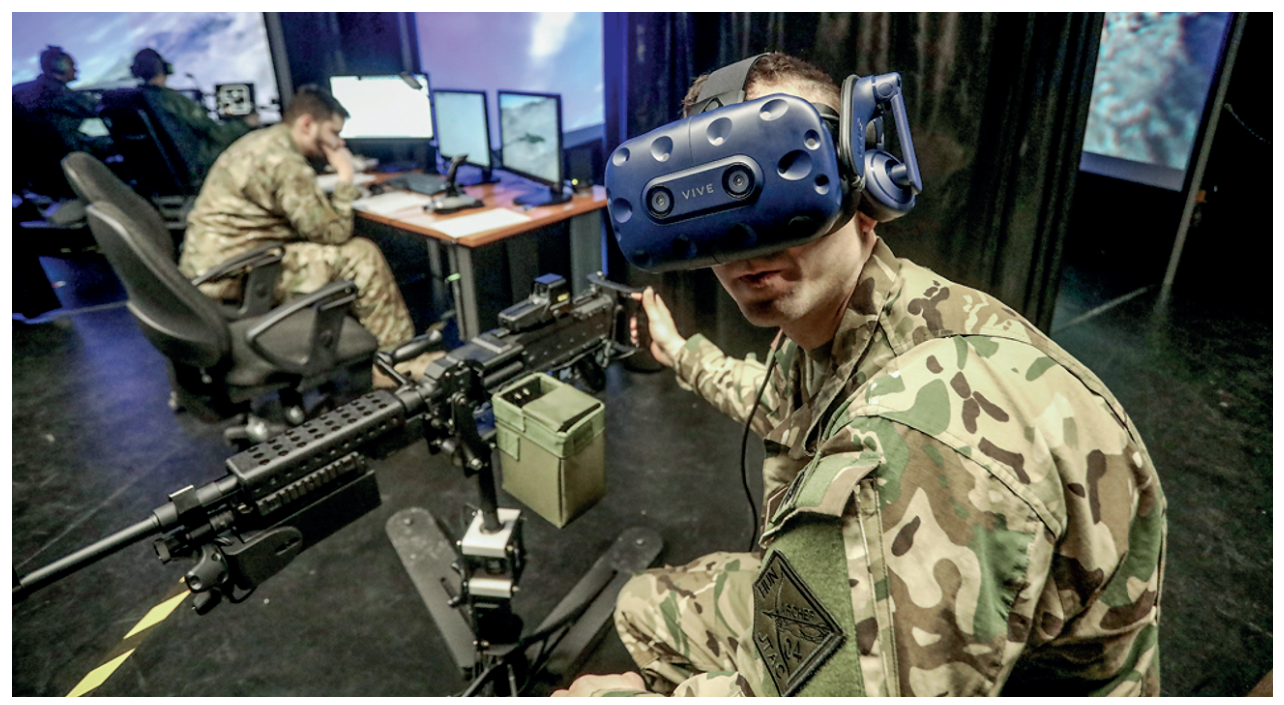

5. ábra

HTC Vive Pro, kereskedelmi forgalomban is kapható VR-sisak az MH 86. Szolnok Helikopterbázis szimulátorközpontjában, helikopteres ajtólövész fején.

Forrás: Trautmann i. m. (2. li.)

20 Oculus Rift S termék gyártói oldala. Elérhető: www.oculus.com/rift-s/ (A letöltés dátuma: 2020. 05. 20.) 


\section{A technológiai fejlödése mint az elterjedés kulcsa}

Visszatekintve az időben láthatjuk, hogy már az 1990-es évek végén hazánkban is ki lehetett próbálni virtuálisvalóság-sisakokat, de ezek használata, teljesítménye-emiatt immerzivitása - nagyon gyenge volt. A kijelzők nagyon kicsi részt fedtek le a látótérből, másodpercenként nem tudták elérni a 20 képkocka kijelzését - ami a minimális lenne a folyamatos mozgás érzékeltetéséhez -, a kép a mozgáskor homályossá vált (motion blur), a fej követése lassú és pontatlan volt. ${ }^{21}$ Technológiai szempontból több sarkalatos pontot tudunk azonosítani, amely a 2010-es évek végére lehetővé tette, hogy a mai, kereskedelmi forgalomban, megfizethető áron kapható rendszerek olyan szintü virtuális élményt tudjanak nyújtani, hogy az kiképzésre is használható legyen, illetve akár saját fejlesztéseket lehessen rá építeni. Az egyik sarkalatos pont az „olcsó" lencsék kérdése, amelyet az Oculus cég kezdett el alkalmazni, oly módon, hogy a drága üveglencséket olcsóbb, speciális mủanyag lencsékkel helyettesítették. A lencsék körülbelül $5 \mathrm{~cm}$-re helyezkednek el a szemektől, így a kijelző képének fókuszálásához nagy görbületű, vastag (széles), ezáltal nehéz lencsék szükségesek, így ezek a lencsék szinte minden eszközben Fresnel (szegmentált) lencséket jelentenek (6. ábra).

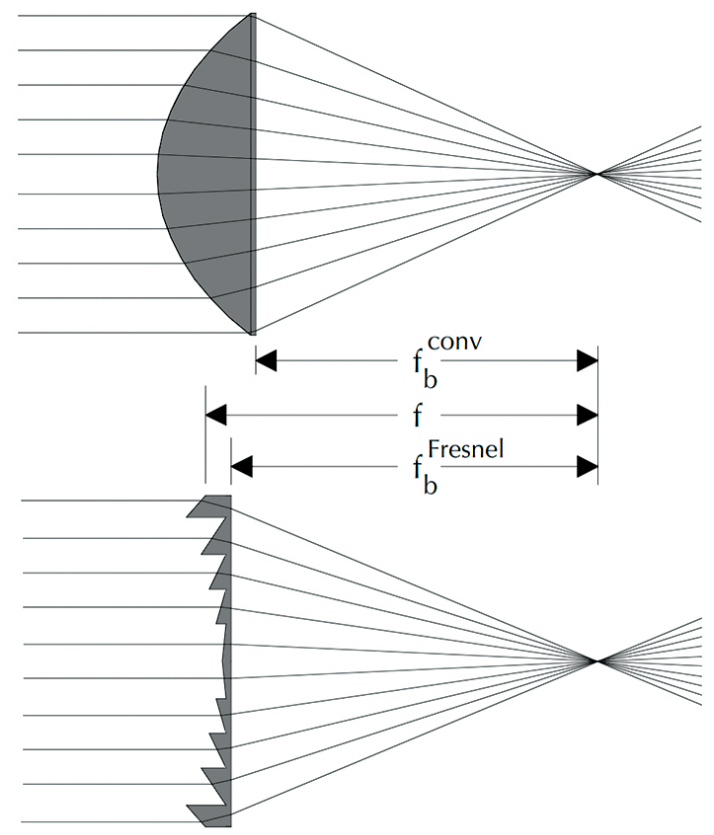

6. ábra

Azonos, pozitív fókusztávolságú hagyományos és Fresnel kollektorlencse szerkezete.

Forrás: Fresnel Lens Brochure. Elérhető: www.fresneltech.com/hubfs/Spec\%20Sheets/Fresnel\%20Lens\%20 Brochure.pdf (A letöltés dátuma: 2020. 05. 20.)

21 A szerző saját tapasztalata. 
Ugyan a szegmentált lencséknek vannak hátrányai a hagyományos lencsékhez képest, de ez csak minimálisan rontja az élményt, föleg a perifériás látómezőben, mivel optikai gyengeségeit szoftveresen feljavítják. Olyan esetekben, ahol szemkövetési adatok is rendelkezésre állnak (mint például a HTC Vive Pro esetén), további szoftverkönyvtárak szerezhetők be, amelyek digitális javítólencseként funkcionálnak, a látott képet tökéletesítik. ${ }^{22} \mathrm{~A}$ kijelzők is elérték azt a miniatürizálási szintet (pixelsürüséget), hogy ezeket HMD-ben lehessen használni, a Pimax Vision 8K PLUS / X termékek például szemenként $4 \mathrm{~K}$ felbontású képet biztosító panellel készülnek. ${ }^{23} \mathrm{~A}$ lencsének és a kijelzőknek köszönhetően a látótér (vízszintes látószög) már a kereskedelmi termékeknél is 100-200 fok között van, ami már bőven elegendő a virtuális élményhez. Az ipari és kiképzési célra fejlesztett Varjo VR-2 például olyan újításokat próbál bevezetni, mint a szemenkénti dupla lencse, illetve több kijelző képének kombinálása. ${ }^{24}$ Ezzel a megoldással sikerült nagy - az emberi szemével azonos - felbontást elérniük, de a vízszintes látószöget így csak 87 fokig tudták növelni. A lencséken és kijelzőkön túl a nagy precizitású, mikroelektronikai giroszkópok, gyorsulásmérők pontosságának javulása, árának csökkenése is alapvető szükséglet volt a technológia térnyeréséhez. Ezen eszközök feladata, hogy adatokat szolgáltassanak a fej helyzetéröl a valós térben, ami aztán a virtuális térben képződik le. Korábban a pontos fejkövetés (tracking) megvalósítása nehézkes volt, elcsúszások történhettek (drift), amelyeket mára már teljesen kiküszöböltek a szenzorfúzió és a mesterséges intelligenciával támogatott képfeldolgozás segítségével. A HMD súlyának csökkentése is sarkalatos pont, a HTC Vive Pro-ban például a fő elektronika két kisméretű alaplapon kapott helyet, amelyekre a szükséges számítási kapacitást és jelfeldolgozást integrálni tudták. A komplexitás érzékeltetése érdekében érdemes számba venni, hogy tulajdonképpen milyen építőelemekből is áll össze ez az elektronikai rész (7. ábra). Az egyik alaplap a szenzor adatainak feldolgozásához szükséges elemeket, a másik pedig az audiovizuális feldolgozás elektronikáját tartalmazza. A szenzor alaplapon egy alacsony fogyasztású Atmel SAM G55J, ${ }^{25}$ ARM Cortex-M4 RISC processzor alapú 32-bites mikrovezérlő kapott helyet, kiegészítve 2 darab ultraalacsony fogyasztású NRF24LU1 ${ }^{26}$ chip-be ágyazott 2,4G Hz-es rádiófrekvenciás rendszerrel, valamint 4MB-os Winbond W25Q32JV27 flash memóriával. Az alaplap fő része, amely a képfeldolgozásért felel egy Alpha Imaging Technology AIT8589D képfeldolgozó processzor kiegészítve egy iCE40HX8K programozható kapumátrixszal, ${ }^{28}$ amely - szintén ezen az alaplapon található - Triad

22 ProEye Unity Plugin. Almalence Inc. Elérhető: https://almalence.com/proeye2x/ (A letöltés dátuma: 2020. 05. 20.)

23 PiMax Vision 8K Plus. Elérhető: www.pimax.com/products/vision-8k-plus-withoutmas\#bundle (A letöltés dátuma: 2020. 05. 20.)

24 Varjo VR-2 Pro. Elérhető: https://varjo.com/products/vr-2-pro/ (A letöltés dátuma: 2020. 05. 20.)

25 Atmel SAM G55J gyártói adatlapja. Elérhető: http://ww1.microchip.com/downloads/en/DeviceDoc/Atmel-11289-32-bit-Cortex-M4-Microcontroller-SAM-G55_Summary-Datasheet.pdf (A letöltés dátuma:2020. 05. 20.)

26 nRF24 chipek gyártói adatlapja. Elérhető: www.nordicsemi.com/Products/Low-power-short-range-wireless/ nRF24-series (A letöltés dátuma: 2020. 05. 20.)

27 W25Q32JV gyártói adatlapja. Elérhető: www.winbond.com/resource-files/w25q32jv\%20dtr\%20revf\%20 02242017.pdf (A letöltés dátuma: 2020. 05. 20.)

28 iCE4OLPHX gyártói adatlapja. Elérhető: www.latticesemi.com/ /media/LatticeSemi/Documents/DataSheets/ iCE/iCE40LPHXFamilyDataSheet.pdf (A letöltés dátuma: 2020. 05. 20.) 
Semiconductor TS423129 második generációs fény-digitálisjel-konverterek (fényérzékelők) által kapott jeleket tudja előfeldolgozni. Ezek az elemek felelősek a követésben alkalmazott külső infravörös fényforrások (világítótornyok) jeleinek feldolgozásáért. A rendszerben található még mikroelektronikai alkatrészek formájában gyorsulásmérő közelségérzékelő és giroszkóp is. A kisebb alaplap felel a számítógépből érkező audiovizuális jelek feldolgozásáért és kijelzőkre juttatásáért, illetve a HTC Vive Pro-ban lévő kamerák képének visszajuttattatásáért a számítógéphez. Az alaplapon található chipek közül, teljesítmény szempontjából említésre méltó a központi, Analogix ANX7530, ${ }^{30}$ 4K Ultra-HD (4096 × 2160p60) felbontású display port szabványú jelvevő, amely kiegészül két MIPI-DSI ${ }^{31}$-csatornával.

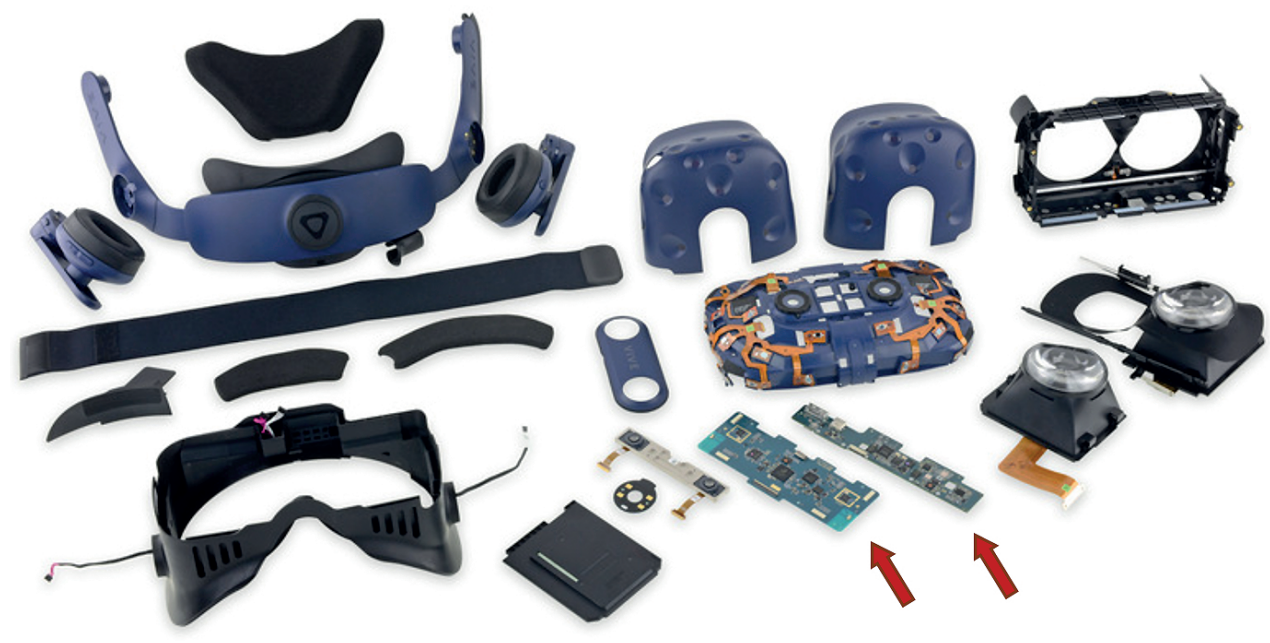

7. ábra

A HTC Vive Pro szétszedett állapotban: jól látható a két darab, kis méretű alaplap.

Forrás: HTC Vive Pro Teardown. 2018. Elérhető: www.ifixit.com/Teardown/HTC+Vive+Pro+Teardown/106064 (A letöltés dátuma: 2020. 05. 20.)

A szenzorok mintavételének gyorsulása (általában 1000 Hz), adataik kis késleltetési idejü átvitele, az optikai érzékelés pontosítása alapvetően szükséges volt ahhoz is, hogy a VR-rendszerek beviteli eszközeit - kontrollereket - is jól lehessen használni. A virtuális térben a kontrollerek modellezése és a pozíciókövetés ma már olyan pontos, hogy a virtuális térben található kontroller egy centiméternél kisebb átmérőjü gombját - ha az nem is a felhasználó kezében van -, csak a virtuális képet használva („vakon”), teljes biztonsággal, első próbálkozásra meg lehet érinteni. ${ }^{32}$ Ez azt jelenti,

29 TS4231 gyártói adatlapja. Elérhető: www.triadsemi.com/product/ts4231/ (A letöltés dátuma: 2020. 05. 15.)

30 ANX7530. Elérhető: www.analogix.com/en/products/dp-mipi-converters/anx7530 (A letöltés dátuma: 2020. 05. 20.)

31 A MIPI-DSI: egy soros, nagy felbontású, alacsony fogyasztású képtovábbító interfész szabvány, amely mobil, VR- és autóiparban használt eszközökre van optimalizálva.

32 A szerző saját tapasztalata. 
hogy a saját test érzete alapján tudjuk pozícionálni kezünket a virtuális térben, amihez az szükséges, hogy a virtuális és valós tér, valamint a mozgás 1: 1 leképezése történjen meg. Az 1: 1-es leképezés kis távolságokon jól müködik, nagyon pontos, mivel a virtuális képeket előállító szoftverek nagy figyelmet fordítanak erre. A képet a virtuális látószög (Field of View-FOV) finomhangolásának segítségével tökéletesítik. Nagyobb távolságok esetén ugyanakkor a térérzékelés még nem mindig tökéletes, de ez is csak bizonyos esetekben jelentkezik érzékelhető formában, mivel általában ezek szoftveres kompenzációjára is figyelmet szentelnek a gyártók. ${ }^{33}$ Bár a jelenleg elterjedt rendszerek - amelyek vizsgálatom tárgyát képezik - már teljesen át tudják helyezni a virtuális térbe a felhasználót, a fejlesztések nem álltak meg, a gyártók egyre nagyobb látószög, képfrissítési frekvencia és képfelbontás elérésére törekednek, valamint olyan plusz funkciókat építenek be, mint a szem követése vagy a háromdimenziós hangzás.

\section{A vizsgált VR-rendszerek elemeinek müködése}

\section{Audiovizuális szimuláció}

Ahhoz, hogy megérthessük, mire lehet és mire nem célszerű alkalmazni ezeket az eszközöket, érdemes áttekinteni a jelenlegi rendszerek működési alapjait. A HMD-k egy-egy (vagy egy, mindkét szemet kiszolgáló) kijelző képét teszik láthatóvá, külön-külön a jobb és bal szem számára, speciális lencséken keresztül úgy, hogy agyunk háromdimenziós képet tudjon készíteni a két képből. Ezt a háromdimenziós képet másodpercenként minimum 40-szer frissíti, készíti el (render) a rendszer úgy, hogy fejünk valós mozgását, pozícióját is leképezi a virtuális térre. Így, amikor a fejünket forgatjuk, mozgatjuk, akkor a látóterünk a szintetikus világban teljes szinkronban marad, emiatt az érzet - pl. egy körbenézés esetén - tökéletesen valódinak hat. Ezt a lekövetést nagyon nagy sebességgel és nagyon pontosan kell végezni, ehhez kamerák, gyorsulásérzékelők és giroszkópok adatait dolgozzák fel szenzorfúzió segítségével, sőt a kamerák képeinek mesterséges intelligencia által történő kiértékelésére is sor kerül. A fej és más „input"-eszközök mozgásának és pozíciójának optikai követése több kamerával oldható meg. A kamerák által készített kétdimenziós képeken képfeldolgozással azonosított referenciapontok pozíciójából számítják ki a térbeli pontokat és azok alapján az eszköz helyzetét. Az optikai követésre két fő megoldási módszer létezik, az egyik az „inside-out” (belülről kifelé), a másik az „outside-in” (kintröl befelé). ${ }^{34}$ A kettő közötti alapvető különbség a mozgást figyelő kamera elhelyezkedése. A régebbi rendszerekben az egyszerübb „outside-in" megoldást alkalmazták, amelyhez a teremben el kellett helyezni kamerákat (bázisállomásokat), amelyek a felhasználói térben figyelték a HMD pozícióját az azon lévő aktív pozíciójelölők segítségével. Az újabb és kényelmesebb megoldás

33 Daniel Finnegan: Compensating for distance compression in virtual audiovisual environments. Doktori értekezés. University of Bath, 2017. Elérhető: https://ps2fino.github.io/documents/Daniel_J._Finnegan-EngD-Thesis.pdf (A letöltés dátuma: 2020. 10. 16.)

34 M. Ribo - A. Pinz - A. L. Fuhrmann: A new optical tracking system for virtual and augmented reality applications. Proceedings of the $18^{\text {th }}$ IEEE Instrumentation and Measurement Technology Conference. Rediscovering Measurement in the Age of Informatics, 2001. 
az „inside-out”, amely esetben minimum 3 kamera van felszerelve a HMD-re, amelyek a környezet képeiből számítanak pozíciót, mesterséges intelligencia segítségével úgy, hogy a képeken jól megkülönböztethető részeket (feature) keresnek, és azok elmozdulását vizsgálják, amit aztán visszaszámítanak térbeli pozíciókká.

\section{Kéz szimulációja}

A valóságos hatást már a HMD önmagában biztosítja olyan obszervációs jellegű esetekben, ahol nem szükséges a tér manipulálása. A virtuális térrel való interakcióhoz különböző beviteli eszközöket kell alkalmazni, amelyek egyre szélesebb körben teszik lehetővé a mozgás digitalizálását. A kiképzési szimuláció szempontjából a kéz szimulálása, annak úgynevezett kontrollerei a legfontosabbak, ezek követik le a kéz és az ujjak mozgását. Elterjedt megoldás, hogy két darab, a jobb és bal kézben tartott, vezeték nélküli, TV-távirányító méretü, ergonomikusan kialakított eszközt alkalmaznak, ami a követéshez infravörös tartományú fényt bocsájt ki, háromdimenziós alakzatba rendezett LED-ek segítségével. Az előbb említett megoldásoknál a HMD és kontrollerek követését ugyanaz a kamerarendszer végzi. A virtuális kéz pozíciójának érzékelésén felül az ujjak szimulációját kell elvégezni, amihez alapesetben érintésérzékelőket, nyomógombokat, miniatür analóg joystickokat (thumbstick) vagy a laptopokéhoz hasonló érintésérzékelő felületeket (touchpad) alkalmaznak (8. ábra).

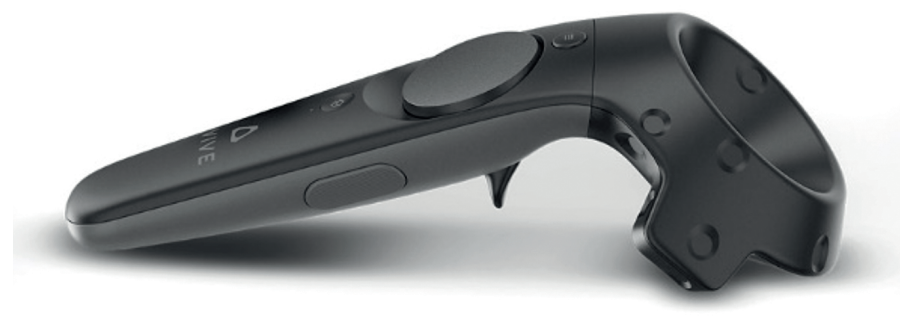

8. ábra

A HTC Vive Pro Controller - a kéz mozgásait digitalizáló eszköz. A gömbölyített fejrészen megfigyelhetök az optikai követést lehetövé tévő infravörös LED-ek bemélyedései, illetve a száron lévő érintöfelület (touchpad).

Forrás: HTC Vive Pro Series. Elérhető: www.vive.com/eu/product/\#pro\%20series (A letöltés dátuma: 2020. 05. 20.)

Megfigyelések alapján, a kéz és ujjak mozgásának virtuális térbe történő átvitele olyan pontos és egyszerü, hogy 4-5 percnyi tanulás, gyakorlás után egyszerü feladatok készségszinten végezhetők, mint például virtuális papírrepülő eldobása, nyomógombok és forgókapcsolók múködtetése, íj használata. ${ }^{35}$ Körülbelül 10 perc gyakorlás után pedig még precízebb feladatok végezhetők el nagy biztonsággal, olyanok, mint - virtuális kézben tartott, virtuális - fegyver kezelőszerveinek múködtetése vagy mint a töltőfogás

35 Oculus Rift S rendszert használva, Oculus First Steps programot futtatva, 12 fő, 6-50 év közötti embereknél (nem reprezentatív, nem formális felmérés). 
elvégzése, a tokfedél felnyitása, a heveder befüzése. Bár ezek még nem teljes pontossággal követik a valós mozdulatsort, de a végrehajtáshoz a kéz pontos pozicionálására és az ujjak koordinált használatára van szükség. A kézbeviteli eszközök esetén érdemes még megjegyezni, hogy egyszerü vibramotorok segítségével bizonyos érintésekről a felhasználó rezgés formájában visszajelzést kap. A kiképzéstámogatás szempontjából már így is nagyon sok lehetőséget rejt ez a „polcról levett” megoldás, amely általában a HMD-t és a kontrollert tartalmazza. A kéz és ujjak leképezéséhez a legjobb, de költségesebb megoldás a speciális kesztyük vagy az Ultraleap által kifejlesztett kamerákkal és infravörös kamerákkal megvalósított kézkövetési technológia alkalmazása. ${ }^{36}$

\section{Mozgás szimulációja}

A kiképzés realitásérzete és a hatás komplexitása tovább fokozható olyan kiegészítő berendezések bevonásával, mint a digitális „taposómalmok” (omni-directional treadmill, $O D T)^{37}$ vagy a heptikus ${ }^{38}$ mellények.
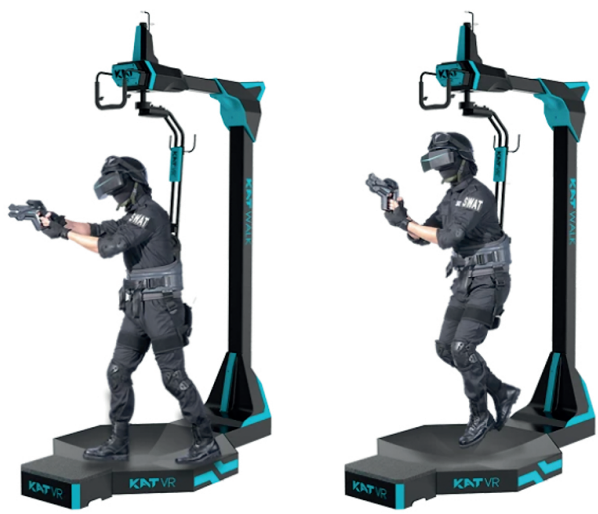
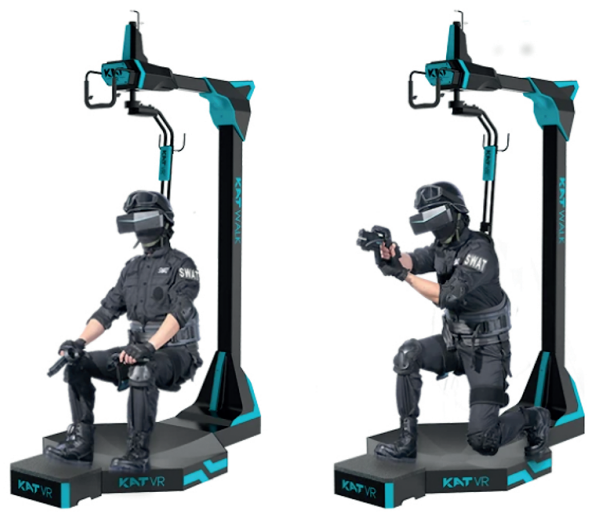

9. ábra

Virtuális „taposómalom” (ODT) a helyváltoztatás életszerübb digitalizálásához alkalmazható. Forrás: KatVR gyártói oldal. Elérhető: www.kat-vr.com/products/kat-walk-premium-vr-treadmill (A letöltés dátuma: 2020. 06. 28.)

További VR-rendszer kiegészítőket is találhatunk még a piacon, mint például a tapintást is átvivő (imitáló) kesztyűk vagy a 3D-mozgatást biztosító székek, de ezek jelen vizsgálat szempontjából nem játszanak fontos szerepet. Mivel a virtuális, háromdimenziós világ leképezéséhez nagy számítási kapacitás szükséges, ezt általában egy különálló, kábelekkel csatlakoztatott számítógép végzi. A kábel nagy sávszélességü és kis késleltetésű adatátviteli csatornát jelent a HMD és a számítógép között,

36 Ultraleap kézdigitalzáló eszköz. Elérhető: www.ultraleap.com/tracking/ (A letöltés dátuma: 2020. 05. 20.)

37 Vasyl Tsyktor: 6 Best VR Treadmills to Try in 2020. 2020. Elérhetö: https://cyberpulse.info/best-vr-treadmills/ (A letöltés dátuma: 2020. 05. 20.)

38 A heptikus ruházat, mellények célja, hogy a virtuális térben a virtuális testet érő behatásokat tapintási inger formájában átvigye a felhasználó testére. Elérhető: www.bhaptics.com/tactsuit/ (A letöltés dátuma: 2020. 05. 20.) 
ezen keresztül küldik át a szenzorok adatait és magukat a renderelt képkockákat is. A gyakorlatban ez egy 5 m-szer 5 m-es mozgásteret eredményez, ami egy - nem jármühöz kötött - kiképzési feladat szimulációja esetén ritkán elegendő. A mozgás a kézi beviteli kontrollerekkel megoldható (gomb vagy joystick müködtetése esetén adott irányba indul a személy), de a kiképzés szempontjából leghatékonyabb módszer az előbb említett többirányú taposómalmok (ODT) használata, amelyek csúszós felület és speciális cipő vagy görgők segítségével imitálják a járás és futás mozdulatait úgy, hogy a felhasználó valós térbeli pozíciója nem változik (9. ábra). A személy tehát, ha a virtuális térben mozogni szeretne, akkor a lábát kell használnia, sétálhat, futhat. A másik lehetőség - amelyet termekben szoktak használni, így továbbra is valamilyen szinten korlátozott mozgástérrel -, hogy a megfelelő specifikációjú hardvert egy hátizsákba teszik, és onnan futtatják a szimulációt, akár több szinkronizált résztvevővel is. ${ }^{39}$ Ilyen hátizsákok láthatók a 3. és 4. ábrán. Szoftveres megoldással is kísérleteznek, amellyel a felhasználó érzékelését becsapva, a való világban enyhe íven történő mozgást vezetik át a virtuális tér egyenes mozgására. Ezáltal egy legalább 22 méter sugarú körben a felhasználó korlátlan távolságokra tud eljutni azt gondolva, hogy egyenesen halad, mert az elfordulás az érzékelési határ alatt (below sensing rate-BSR) marad, valamint a több helyről kapott érzékelése egyenes mozgást éreztet vele. Ez a megoldás szórakozás, játék céljaira jól megfelel, de kiképzési feladatokra csak nagyon korlátozottan alkalmazható, mert ott az egyik legfontosabb szempont a pontos egyezés a virtuális és valós tér között.

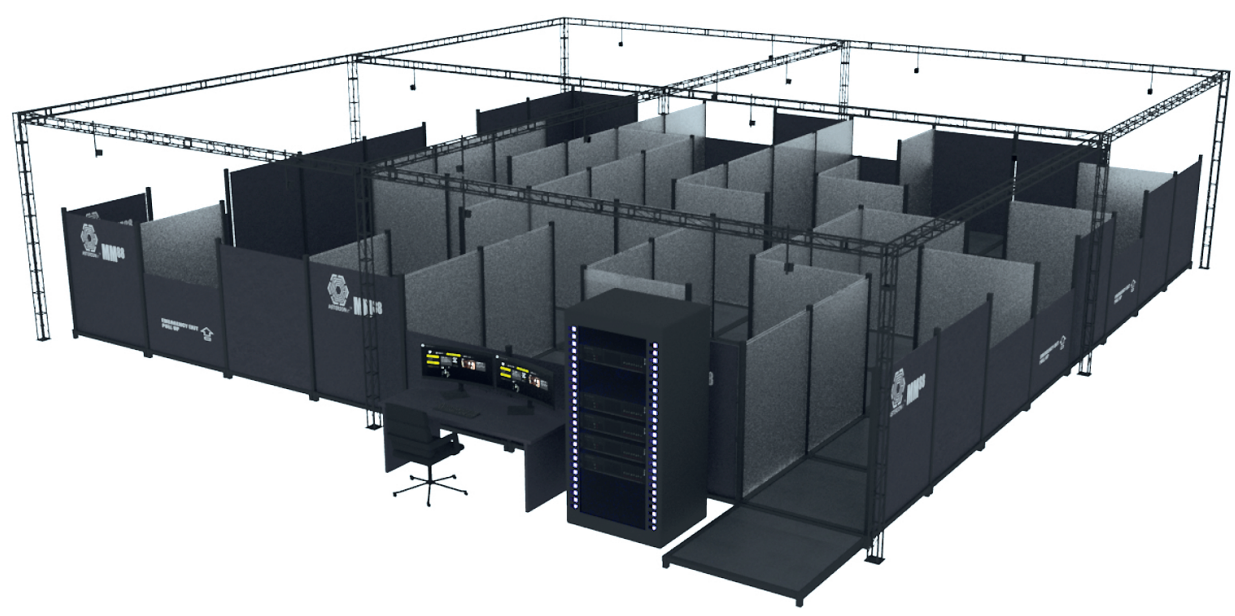

10. ábra

Asterion VR-cég ModulMaze ${ }^{\mathrm{TM}}$ CQB rendszerének képe. A virtuális falakat fizikai falakkal egyeztetik a szimuláció során.

Forrás: Asterion VR hivatalos oldala (8. lj.)

39 Madalina Dinita: 4 VR backpack PCs for an amazing experience. Elérhető: https://windowsreport.com/best-vrbackpack-pcs/ (A letöltés dátuma: 2020. 05. 20.) 
Az Asterion VR-cég rendszere egy speciális $\mathrm{CQB}^{40}$ "tactical progression training" eszközt is ajánl, aminek a lényege, hogy könnyü, szabadon rendezhető padló- és oldalpanelekből fizikai helyiségeket alakítanak ki, amelyek teljesen szinkronban vannak a virtuális térrel. Ezáltal - a föleg épületátvizsgálás jellegü feladatok során - a kiképzettek érzik a falat, a sarkokat, amelyek a virtuális térben leképezett feladatok alapján tetszőlegesen átrendezhetők.

\section{Fegyverek, taktikai eszközök a virtuális térben}

A taktikai VR-szimulációk során a legszerencsésebb, ha a kiképzendő a saját fegyverével vagy ahhoz nagyon hasonló fegyverrel hajthatja végre a gyakorlatot. Ilyen esetekben a virtuális térben szimulált fegyver és a valós térben létező fegyver vagy fegyvermodell fizikai és virtuális paramétereit, tulajdonságait szoftveresen is egyeztetni kell. Az így felkészített rendszerekben (ezt már a 2010-es VIRTSIM is kezelte) a tárcserék, fegyver kezelőszerveinek modellezése is megtörténhet. Itt is találhatunk olcsóbb, nem teljes megoldásokat, amelyek föleg a játékra készülnek, mert a fizikai és virtuális egyeztetés nem pontos, nem kalibrált. A kezelőszervek a térben másképpen helyezkednek el, ezért kiképzésre használva akár rossz beidegződéseket is okozhatnak. Ilyen megoldások még a Beswin VR-cég kézi HTC Vive Pro kontrollerekre helyezhető M4 adaptere (11. ábra), vagy az elektronikus visszarúgással ellátott AK47VR Rifle megoldása, ahol különálló kiegészítőt HTC Vive trackert (mozgáskövetőt) 2.0 szereltek fel.

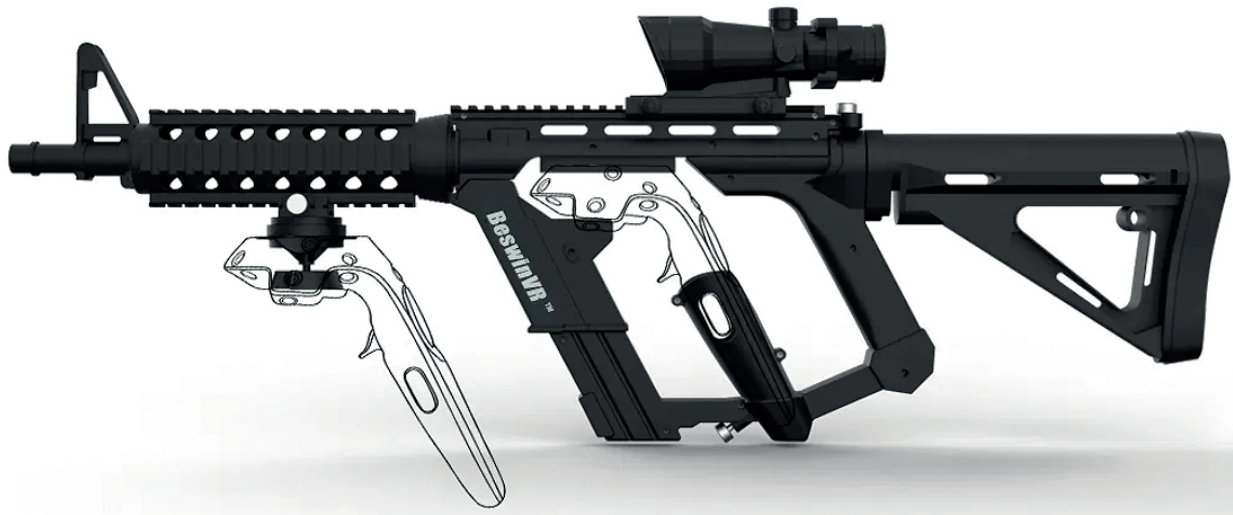

11. ábra

BeswinVR M4 Rifle adapter. A képen látható a hagyományos kézi kontrollerek mágneses illesztésének módja. Forrás: BeswinVR gyártói oldala. Elérhető: www.beswinvr.com/ (A letöltés dátuma: 2020. 05. 20.)

A különálló mozgáskövetőre (tracker-re) mint kereskedelemben kapható ilyen célú illesztő megoldásra épít a LeadTech cég is, de már azzal a céllal, hogy az eszközeit valós fegyverekre szereljék (12. ábra). A rendszerükhöz viszont már szállítanak szoftverfejlesztő

40 Close Quarter Battle - épületharc, épületen belüli harc. 
csomagot (SDK ${ }^{41}$-t) is, amivel a valós fegyver paraméterei modellezhetők, beállíthatók a virtuális térben. A játékiparban több cég is foglalkozik hasonló beviteli kiegészítők fejlesztésével, ahol jelenleg az egyik fő kutatási terület a visszarúgás modellezése, amelyre korábban szén-dioxidos, airsoft fegyverekhez hasonló megoldást használtak, de manapság elektromágnes által lineárisan mozgatott tömeggel érik el a hatást. Ha a kiképzési célú eszközöket nézzük, az egyik megoldás az Asterion cég Thor trackere, amelynek segítségével bármilyen valós fegyvert be lehet vinni a virtuális térbe úgy, hogy a doboz alakú tracker Picatinny (MIL-STD-1913) sínre rögzíthető, így pontosan van egyeztetve a csőtengellyel és az adott fegyver háromdimenziós virtuális modelljével.

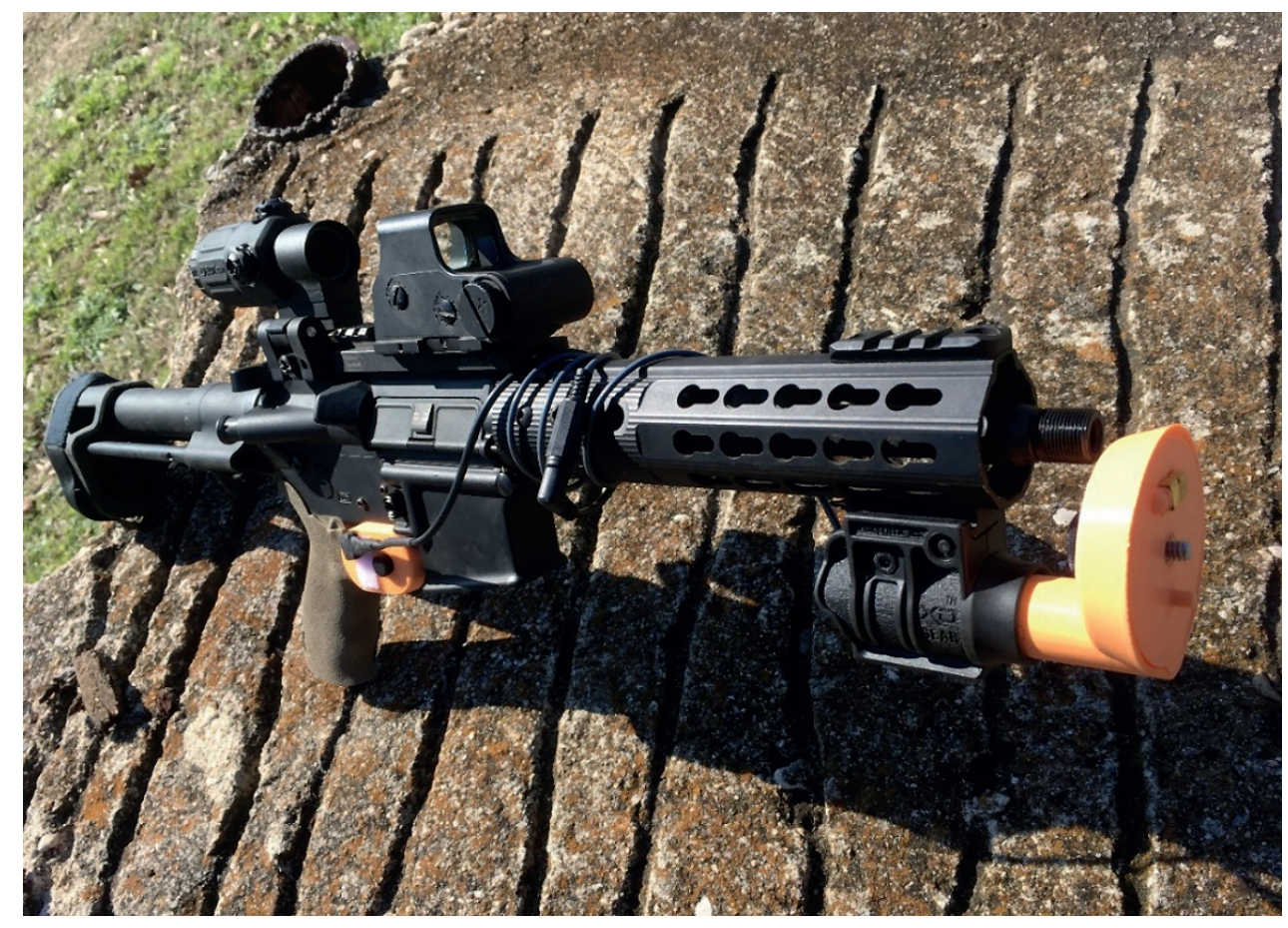

12. ábra

Lead Tech cég megoldása a fegyverek virtualizációjára. A sárga konzol a kereskedelmi forgalomban kapható HTC Vive Tracker 2.0-t tud valós fegyverhez illeszteni.

Forrás: Chip Northrup: Using Your Firearm in VR Simulations and Games. 2019. Elérhető: https://clazer. club/2019/01/03/using-your-firearm-in-vr-simulations-and-games/ (A letöltés dátuma: 2020. 05. 20.)

A használhatósághoz természetesen még minimum az elsütőbillentyű elektronikus bekötése is meg kell hogy történjen az ilyen rendszereknél. A cég emellett használatra kínál a rendszerhez előre gyártott méretazonos szén-dioxidos légfegyvereket is, amelyek a valós fegyver visszarúgását 70\%-os erővel tudják szimulálni. Ehhez hasonlóan

41 SDK: Software Development Kit - Szoftverfejlesztői csomag az adott feladat, feladatkör programozásának segítésére. 
a föleg rendvédelmi feladatok gyakorlására létrehozott Apex Officer VR taktikai szimulációs rendszerének esetében az eszközöket előre modellezték és legyártották. A rendszer érdekessége, hogy a járőr teljes felszerelése rendelkezésre áll a szituációk megoldásához. A karabélyokon, sörétes puskán, pisztolyokon kívül nem halálos eszközöket is bevethetnek, mint elemlámpa, többféle elektromos sokkoló, bot vagy akár OC-spray (paprika spray). ${ }^{42}$ Egy saját fejlesztésü szimulátorrendszer esetén az ilyen eszközök és fegyverek fizikai modellezése, virtuális térbeli használatához való előkészítése nem jelent kihívást a mára már jól hozzáférhető additív gyártástechnológiák, ${ }^{43}$ elterjedt 3D-szkennelési és -vizualizációs technikák és mikroelektronikai építőelemek modularitásának köszönhetően. ${ }^{44}$

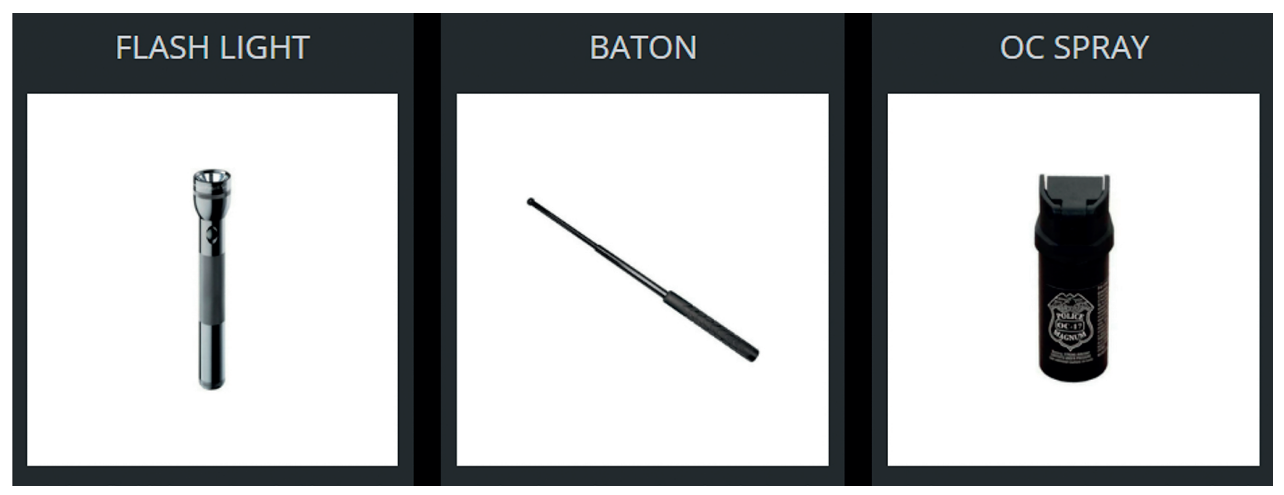

13. ábra

Az Officer VR-rendszerben használható arzenál egy része. Elemlámpa, bot és paprikaspray. Forrás: Apex Officer i. m. (42. lj.)

\section{Összegzés}

A cikkben azokat a jelenleg is könnyen elérhető virtuális valóság eszközöket és technológiai megoldásokat kívántam elemezni, amelyek akár azonnal rendelkezésre állnak egy saját kiképzőeszköz kialakításához szükséges kutatás és tervezési munka megkezdéséhez. Nemzetközi példákon keresztül alátámasztottam, hogy ezek az eszközök és technológiák valóban alkalmasak kiképzési feladatok végrehajtására és kiértékelésére. Vizsgáltam azt is, hogy melyek voltak azok a technológiai fejlesztések, amelyek nélkül a jelenlegi realitásérzet-szintet - ezáltal a kiképzési feladatokra való

42 Apex Officer rendszere által használt fegyver és eszköz modellek. Elérhető: www.apexofficer.com/arsenal (A letöltés dátuma: 2020. 05. 20.)

43 Gál Bence - Németh András: Additív gyártástechnológiák katonai alkalmazásának vizsgálata, különös tekintettel a katonai elektronikai területére. Hadmérnök, 14. (2019), 1. 231-249.

44 Németh András - Szabó A. - Balog F.: 3D virtualizációs és vizualizációs technológiák az eredmények archiválásában. In Hausner Gábor - Németh András (szerk.): Zrínyi-Újvár: Egy 17. századi védelmi rendszer az oszmán hódoltság határán. Budapest, Ludovika Egyetemi Kiadó, 2019. 223-266. 
felhasználhatóságot - nem értük volna el. A komplex kiképzőrendszer összeállításához szükséges egyéb építőelemek is vizsgálatom tárgyát képezték, amelyek alkalmazásával vagy amelyekhez hasonló megoldások kidolgozásával és implementálásával a realitásérzet tovább növelhető.

A tanulmány következő részeiben egyrészt mélyebben kívánom megvizsgálni azokat a technológiára jellemző paramétereket, amelyek ismerete és hatékony kezelése elengedhetetlen egy sikeres perspektivikus kiképzési rendszer kialakítása során, másrészt fel kívánom térképezni azokat a tényezőket, amelyek megnehezíthetik a fejlesztők munkáját. Ezenfelül kitérek azoknak a kompetenciáknak az elemzésére is, amelyek egy hazai projekt beindításához, majd eredményes végrehajtásához szükségesek.

\section{Felhasznált irodalom}

Adams, Rick: Virtual Reality Ramp Up 3D Immersive Environments. Military Technology, 41. (2017), 12. 42-44.

Adorian, P. - W. Staynes - M. Bolton: The Evolution of the Flight Simulator. London, Royal Aeronautical Society, 1979.

Gál Bence - Németh András: Additív gyártástechnológiák katonai alkalmazásának vizsgálata, különös tekintettel a katonai elektronikai területére. Hadmérnök, 14. (2019), 1. 231-249.

Blink, Martin L. - David R. James - John T. Miller II: Research Report 1986: Training Capability Data for Dismounted Soldier Training System. United States Army Research Institute for Behavioral and Social Sciences, 2015. Elérhetö: https:// apps.dtic.mil/dtic/tr/fulltext/u2/a621959.pdf (A letöltés dátuma: 2020. 05. 20.)

DAUNTLESS. Elérhető: www.motionreality.com/dauntless (A letöltés dátuma: 2020. 05. 20.)

Dinita, Madalina: 4 VR backpack PCs for an amazing experience. Elérhető: https:// windowsreport.com/best-vr-backpack-pcs/ (A letöltés dátuma: 2020. 05. 20.)

Finnegan, Daniel: Compensating for distance compression in virtual audiovisual environments. Doktori értekezés. University of Bath, 2017. Elérhető: https:// ps2fino.github.io/documents/Daniel_J._Finnegan-EngD-Thesis.pdf (A letöltés dátuma: 2020. 10. 16.)

Gahlot, Ayushi - Purvi Agarwal - Akshya Agarwal - Vijai Singh - Amit Kumar Gautam: Skeleton based Human Action Recognition using Kinect. International Journal of Computer Applications, (0975 - 8887) Recent Trends in Future Prospective in Engineering \& Management Technology, (2016), 9-13. Elérhető: https:// research.ijcaonline.org/rtfem2016/number1/rtfem45111.pdf (A letöltés dátuma: 2020. 06. 28)

Grove, David: Why the term "every Marine is a rifleman" needs to stop. 2018. Elérhető: www.wearethemighty.com/military-life/why-the-term-every-marine-is-a-rifleman-needs-to-stop (A letöltés dátuma: 2020. 05. 20.)

HTC Vive Pro Series. Elérhető: www.vive.com/eu/product/\#pro\%20series (A letöltés dátuma: 2020. 05. 20.) 
Marlok Tamás: Virtuális valóság alapú taktikai szimulációs kiképzőeszközök hazai fejlesztési...

Lang, Ben: VIRTSIM is the Virtual Reality Platform That Gamers Crave but Can't Have. Road To VR. 2012. Elérhető: www.roadtovr.com/virtsim-virtual-reality-platform/ (A letöltés dátuma: 2020. 05. 20.)

Lozé, Sébastien: Efficient police virtual training environment in VR by V-Armed. 2019. Elérhető: www.unrealengine.com/en-US/spotlights/efficient-police-virtual-training-environment-in-vr-by-v-armed (A letöltés dátuma: 2020. 05. 20.)

Németh András - Szabó A. - Balog F.: 3D virtualizációs és vizualizációs technológiák az eredmények archiválásában. In Hausner Gábor - Németh András (szerk.): ZrínyiÚjvár: Egy 17. századi védelmi rendszer az oszmán hódoltság határán. Budapest, Ludovika Egyetemi Kiadó, 2019. 223-266.

Northrup, Chip: Using Your Firearm in VR Simulations and Games. 2019. Elérhető: https://clazer.club/2019/01/03/using-your-firearm-in-vr-simulations-and-games/ (A letöltés dátuma: 2020. 05. 20.)

Rauchenberger, Markus: Dismounted Soldier Training (U.S. Army). Elérhető: www.flickr. com/photos/soldiersmediacenter/11336074633/ (A letöltés dátuma: 2020. 05. 20.)

Ribo, M. - A. Pinz - A. L. Fuhrmann: A new optical tracking system for virtual and augmented reality applications. Proceedings of the $18^{\text {th }}$ IEEE Instrumentation and Measurement Technology Conference. Rediscovering Measurement in the Age of Informatics, 2001. DOI: https://doi.org/10.1109/imtc.2001.929537

Trautmann Balázs: Képzelt repülés. 2019. Elérhető: https://regi.honvedelem.hu/ cikk/115528_kepzelt_repules (A letöltés dátuma: 2020.05. 20.)

Waitt, Tammy: V-ARMED: Experience Next-Gen Simulation. 2019. Elérhető: https:// americansecuritytoday.com/v-armed-experience-next-gen-simulation-learn-multi-vid (A letöltés dátuma: 2020. 05. 20.)

\section{Jogi forrás}

53/2016. (XII. 16.) NFM rendelet a légijármü és a repülőeszköz személyzet, valamint a repülésüzemi tiszt képzéséről, vizsgáztatásáról, engedélyeiről és a képzésükben részt vevő képző szervezetek engedélyezéséről

\section{Internetes források}

ANX7530. Elérhető: www.analogix.com/en/products/dp-mipi-converters/anx7530 (A letöltés dátuma: 2020. 05. 20.)

Asterion VR. Elérhető: https://asterionvr.com/ (A letöltés dátuma: 2020. 05. 20.) Atmel SAM G55J gyártói adatlapja. Elérhető: http://ww1.microchip.com/downloads/ en/DeviceDoc/Atmel-11289-32-bit-Cortex-M4-Microcontroller-SAM-G55_Summary-Datasheet.pdf (A letöltés dátuma: 2020. 05. 20.)

BeswinVR gyártói oldala. Elérhető: www.beswinvr.com/ (A letöltés dátuma: 2020. 05. 20.) HTC Vive Pro Teardown. 2018. Elérhető: www.ifixit.com/Teardown/HTC+Vive+Pro+Teardown/106064 (A letöltés dátuma: 2020. 05. 20.) 
Marlok Tamás: Virtuális valóság alapú taktikai szimulációs kiképzőeszközök hazai fejlesztési...

iCE40LPHX gyártói adatlapja. Elérhető: www.latticesemi.com/ /media/LatticeSemi/ Documents/DataSheets/iCE/iCE40LPHXFamilyDataSheet.pdf (A letöltés dátuma: 2020. 05. 20.)

KatVR. Elérhető: www.kat-vr.com/products/kat-walk-premium-vr-treadmill (A letöltés dátuma: 2020. 06. 28.)

Korean startup releases VR simulators for military training. Elérhető: www.youtube. com/watch?v=Et5BsV0U1Lw (A letöltés dátuma: 2020. 05. 20.)

Fresnel Lens Brochure. Elérhető: www.fresneltech.com/hubfs/Spec\%20Sheets/Fresnel\%20Lens\%20Brochure.pdf (A letöltés dátuma: 2020. 05. 20.)

Motion Reality, Inc. Twitter-bejegyzése. Elérhető: https://twitter.com/motionreality/ status/821380226919890944/photo/1 (A letöltés dátuma: 2020. 05. 20.)

nRF24 chipek gyártói adatlapja. Elérhető: www.nordicsemi.com/Products/Low-power-short-range-wireless/nRF24-series (A letöltés dátuma: 2020. 05. 20.)

Oculus Rift S termék gyártói oldala. Elérhető: www.oculus.com/rift-s/ (A letöltés dátuma: 2020. 05. 20)

Office of Naval Research (ONR) Global Techsolutions. Elérhető: www.onr.navy.mil/ techsolutions/ (A letöltés dátuma: 2020. 05. 20.)

PiMax Vision 8K Plus. Elérhető: www.pimax.com/products/vision-8k-plus-withoutmas\#bundle (A letöltés dátuma: 2020. 05. 20.)

ProEye Unity Plugin. Almalence Inc. Elérhető: https://almalence.com/proeye2x/ (A letöltés dátuma: 2020. 05. 20.)

TS4231 gyártói adatlapja. Elérhető: www.triadsemi.com/product/ts4231/ (A letöltés dátuma: 2020. 05. 15.)

Tsyktor, Vasyl: 6 Best VR Treadmills to Try in 2020. 2020. Elérhető: https://cyberpulse. info/best-vr-treadmills/ (A letöltés dátuma: 2020. 05. 20.)

Ultraleap kézdigitalzáló eszköz. Elérhető: www.ultraleap.com/tracking/ (A letöltés dátuma: 2020. 05. 20.)

Unreal Engine, Training and Simulation. Elérhető: www.unrealengine.com/en-US/ industry/training-simulation (A letöltés dátuma: 2020. 05. 20.)

Varjo VR-2 Pro. Elérhető: https://varjo.com/products/vr-2-pro/ (A letöltés dátuma: 2020. 05. 20.)

VIRTSIM by $9^{\text {th }}$ Ranger from $3^{\text {rd }}$ until $7^{\text {th }} F e b .2020$. [Maláj Hadsereg - a szerző kiegészítése] Elérhető: www.youtube.com/watch?v=Y0y8hT17-vE (A letöltés dátuma: 2020. 05. 20.)

W25Q32JV gyártói adatlapja. Elérhető: www.winbond.com/resource-files/w25q32jv\%20 dtr\%20revf\%2002242017.pdf (A letöltés dátuma: 2020. 05. 20.) 
